\title{
Longitudinal change in East Timorese tertiary student attitudes to national identity and nation building, 2002-2010
}

\section{Introduction}

This article presents the findings of a longitudinal survey of East Timorese tertiary student attitudes, obtained by conducting a modified version of the International Social Survey Programme (ISSP) national identity module (Dili, August 2002, July 2007 and March 2010). It examines a range of nation-building 'fault lines' in post-independence Timor-Leste, ${ }^{1}$ by focusing on the attitudes of a particular group likely to contribute strongly to future decision-making elites: tertiary students. Where the findings of the first two surveys (Leach 2003, 2008) focused on key aspects of intergenerational conflict over national identity (including the choice of Portuguese as the co-official language), this article offers a different focus. Among other things, it examines the longitudinal evidence for differences in attitudes between students from eastern and western districts, categories that became briefly but intensely politicized in the 2006 political-military crisis. It is argued that the relatively few significant differences in attitudes peaked in the 2007 survey, and were associated with the overt politicization of regional identity within Dili, and with perceptions that East Timorese returning from the diaspora were dominating the post-independence national leadership, rather than with any genuine 'ethnic' or 'regional' variation in attitudes. The most recent survey findings also highlight the ongoing importance of tradition and $a d a t^{2}$ in understandings of political community, but also reveal significant gender differences in attitudes to the political roles of traditional authorities.

1 This article uses the official name 'Timor-Leste' to refer to the post-2002 nation-state, and 'East Timor' when referring to the pre-2002 territory. 'East Timorese' is employed as the demonym throughout.

2 Adat is a widely used Indonesian term referring to custom. The equivalent term in Tetum is lisan.

MICHAEL LEACH is Associate Professor in Politics and Public Policy, Swinburne University of Technology, Melbourne. His primary fields of academic interest are the politics of Timor-Leste and Melanesia. He is the author of 'East Timorese history after independence', History Workshop Journal 61-1, 2006, pp. 222-37, and 'Difficult memories: The independence struggle as cultural heritage in East Timor', in: William Logan and Keir Reeves (eds), Places of pain and shame: Dealing with 'difficult' heritage, pp. 144-61. London: Routledge, 2009. Associate Professor Leach may be contacted at mleach@swin.edu.au. 


\section{Background: Nation and state building}

Following the 2006 political-military crisis, it was clear that Timor-Leste's sense of national identity was weaker than presumed, shallowly rooted and fractured along a variety of generational, regional, linguistic and political lines. The cohesive forms of national community and identity presumed to have existed in the period immediately after the 1999 vote on self-determination were under challenge. The principal challenges to a functional sense of bonded political community were evident not only in the resurgence of regional identities in the urban area of Dili, but also in tensions between modern and traditional understandings of political authority in rural areas, and in intergenerational debates over the meaning and content of both the 'nation' and national identity. While the violent intensification of regional identity within Dili had largely subsided by 2008, the 2007 election results left a legacy of strongly regionalized voter affiliations, with a clear pattern of alignments between certain district groupings and particular factions of the East Timorese political elite.

Nation building refers to the cultural processes of forming a cohesive political community to support the development of a functional state. While the international community is preoccupied with post-conflict state building (focused on issues of governance, institutions, accountability, and the rule of law) (Chandler 2006) the broader processes of nation building (community development, identity formation, national integration) have been relatively neglected. Yet the challenges facing many post-conflict states, such as TimorLeste, derive from both a lack of state capacity and the absence of a socially cohesive 'national' political community, based on a broadly legitimate and unifying sense of national identity. A basic level of social consensus on national values and commitment to a common national project are required to ensure the state enjoys stability, and is seen as a legitimate and representative expression of the political communities it serves. Nation building, in the sense of creating the conditions for social cohesion, political stability and identity formation, is therefore an integral dimension of the state-building process.

For Borgerhoff (2006:103), nation building is the 'deliberate interest- and ideology-based formation of a national format which creates collective identity and affiliation of the population within the nation-state'. Key areas of focus here would include the conventional 'cultural nationalist' areas of national identity, language policy, the development of history and civic education curricula, cultural heritage management, and the development of a national media, linking the state and civil society with a literate citizenry. Naturally, however, attempts by political elites to implement a nation-building 'policy set' occur within specific economic, political and developmental contexts, which may vary greatly between urban and rural areas. Analyses of nation formation may therefore also examine the way prevailing socio-economic structures influence 
the formation or reproduction of political communities; how tensions between modern and traditional conceptions of authority influence popular conceptions of state legitimacy; how nation-building and state-building agendas interact; and how these processes combine, successfully or otherwise, to create 'national' constituencies in support of the state and its institutions.

As Dinnen (2007:3) notes, conscious attempts to develop 'a shared sense of identity and community' among various populations within a state do not necessarily have to foster homogeneity, but must at least produce a sustainable consensus on shared civic goals, and tolerance of heterogeneity. In the context of weak economic development, however, latent social divisions may be compounded in the competition for scarce resources, producing forms of national politics characterized by inter-group contests for the capture of the state, to benefit regional or clan-based patronage networks. As such, while state and nation building should be regarded as conceptually distinct activities, these agendas are inevitably entwined and mutually reinforcing in practice. For example, in providing services 'equally' across the entire nation, and in integrating citizens around a central authority, state provision of services provides a visible and meaningful presence to the nation-state, allowing citizens in different communities to identify more easily with the greater whole. Regional and clan identities are more likely to be seen as effective political vehicles in the absence of a functional state. As Jacobsen (1997:227) argues, ideologies alone cannot make the nation-state as ' $[\mathrm{t}]$ he actual implementation and entrenchment of governmental institutions, both political and administrative ... must be the primary bearers of the national framework, if the nation is to have any continuity'. Conversely, social conflicts and nation-building 'fault lines' in turn have grave consequences for state formation, as has been evident in both Timor-Leste and the Solomon Islands in recent years.

There are also particular challenges of nation and state building in 'new subsistence states' (Nixon 2006) characterized by low levels of economic development, and subsistence agriculture as a predominant mode of economic activity outside cities. As Nixon argues, where a substantial proportion of the national population is reliant on subsistence farming, integration into 'modern' economic and political systems regulated by the nation-state may be minimal. Such environments are normally characterized by the ongoing presence of 'local administrative mechanisms capable of operating independently from the state in accordance with the principles of "traditional authority"'(Nixon 2006:75). His key argument - with primary reference to the formal justice sector - is that the incorporation of some of these local and traditional capacities will improve the wider administration of these states.

Effective nation formation is therefore not just about lateral integration of different groups through 'deliberate' constructions of national identities and interests, but also about the sustainability of relationships between influ- 
ential conceptions of traditional community and modern state institutions, and the potential for 'hybrid' forms to promote stability. As Dinnen (2007:1) notes, nation building in the 1960s and 1970s was commonly conceived of as an 'inevitable' process of transition from traditional forms of authority to a modern political community embodied by the nation-state; and orchestrated through the 'self-conscious production and dissemination of national consciousness' by national elites. In East Timor in the 1970s, for example, the architects of modern nationalism, while drawing on unifying traditional tropes of the 'Maubere' or common people, essentially saw traditional political systems and legitimacy as feudal and backward (Joliffe 1978). The tensions between modern and traditional political notions of political authority remain a key challenge for nation builders in Timor-Leste. For Trindade and Castro (2007), one broad background factor to the 2006 crisis lay in perceptions of the imposition of a modern state, from Dili, without a supporting concept of the 'nation' capable of resonating with collective visions of community and identity in the regions. As Dinnen argues, it is no longer assumed that nation building must necessarily take place in the context of 'modernization', allowing for new concerns with hybrid institutions that link popular conceptions of political authority with the modern state.

Timor-Leste provides a clear example of the challenges of post-conflict nation-building. Following the 1999 violence which precipitated institutional collapse within the territory, East Timor was described as a 'nation without a state'. Prior to the resurgence of violence in April 2006, the United Nations Transitional Administration in East Timor (UNTAET) was considered one of the most successful examples of international state-building intervention (Chesterman 2004). By 2006, however, commentators were discussing the failures of nation building evident in the dramatic rise of 'east-west' violence in Dili; catalysed by tensions within the army between soldiers from eastern and western regions (Kingsbury and Leach 2007). Recidivist violence in Timor-Leste indicated how easily unresolved socio-political tensions could overwhelm abstracted institution-building agendas. A narrow state-building agenda was also domestically criticized for failing to develop a shared sense of identity and community (Trindade and Castro 2007). While overt 'eastwest' tensions in Dili have diminished, regional loyalties remain important factors in patterns of political mobilization and party support. The links between deep-seated personal conflicts within Timor-Leste's small political elite and these regional affiliations remain latent and dangerous ones for national unity. The following section examines a range of national 'fault lines' in Timor-Leste since independence. 
National integration challenges in Timor-Leste, 2002-2010

In Benedict Anderson's classic formulation (1983), creating a 'nation' requires the articulation of a shared identity, history and heritage that transcends real differences of region, ethnicity and language. After a 24-year struggle for independence, the 2002 Constitution of the Democratic Republic of Timor-Leste was a seminal 'official' declaration in a broader contest over national identity. Reinforced by subsequent education and language policies, the founding document of the East Timorese state explicitly addressed official understandings of national identity, national history, and language policy. These official narratives sought to build on the presumed unities that emerged from the resistance era, culminating in the national vote for independence in the 1999 referendum. Since independence, maintaining this unified sense of a common national identity has proven a more challenging task. Timor-Leste has witnessed intergenerational disputes over national identity and official languages (Leach 2003), and wider 'history wars' within the former independence movement over the symbolic 'ownership' of the independence struggle and its core historical narratives (Leach 2006, 2009). The dissonance between popular and official narratives of national identity is one aspect of these challenges.

One touchstone issue in the early years of independence concerned the choice of official languages and the official cultural affiliations of the independent state. The 2002 survey findings suggested that a younger generation of East Timorese sought to contest the 'official' linguistic and cultural affiliations of the nation-state after independence, while strongly supporting other 'official' narratives of national history, including the valorization of the East Timorese resistance (Leach 2003). Specifically, the 2002 survey highlighted considerable unease in this demographic over the choice of Portuguese as coofficial language. This signal issue of intergenerational tension reflected the fact that older nationalists still politically dominate the post-independence state, and significant numbers of younger people felt misrecognized by some 'official' articulations of national identity reflected in the East Timorese constitution and key policies of post-independence governments. As such, while the process of articulating the cultural components of nationalism may be metaphorically understood as one of 'imagining' a nation, in practice it may involve the attempted universalization of the cultural and political values of a dominant nationalist grouping - and contribute to social conflict after independence (Leach 2002:45). By the 2007 survey, however, the findings indicated a significant growth in the acceptance of the co-official status of Portuguese language in the tertiary student demographic (Leach 2008). As is noted further below, these levels had stabilized in the 2010 survey. Other nation-building fault lines, however, were also in evidence.

By the April 2006 crisis, the political-military crisis (often referred to as the 
'east-west' conflict) within the army, police, and between Lorosa'e (eastern) and Loromonu (western) youth gangs in Dili clearly demonstrated the difficulty of sustaining a unified vision of national identity among the ethnically and linguistically diverse populations of Timor-Leste. In particular, the crisis highlighted the way the nation-building process had been greatly complicated by 'recognition' style struggles over the relative contributions of various political actors to the achievement of East Timorese independence. Resentments within the new East Timorese army (F-FDTL) between former resistance fighters from the east and newer recruits from the west, over which 'region' had contributed more in the war of resistance, were compounded by apparent cases of discrimination (in promotions and living conditions) against soldiers from the west. While easterners formed only a slim majority of overall forces (56\%), veterans from the eastern districts, where the armed resistance had ultimately been more sustainable, dominated the officer ranks $(85 \%) .^{3}$ Though largely ignored by the media, these so-called 'regional' splits were entwined with issues of intergenerational tension within army ranks. ${ }^{4}$ These in turn appeared to catalyse disaffected and unemployed urban youth in Dili, particularly those from the west who felt disrespected by reported claims among senior army officers that easterners had dominated the resistance (Grove et al. 2007:4).

Significantly, there were no examples of 'separatist' discourse at any point of the crisis. Even at the peak of these short-lived but intense conflicts, none of the protagonists sought to deny a common historical bond, or the view that all East Timorese should form a single nation - even if, as Kammen (2003) has observed, the nationalist/traitor trope is frequently employed in a range of social conflicts. As such, the crisis and other precursor conflicts are best viewed as struggles for recognition (Honneth 1995): to secure acknowledgement of contributions to the valued common project of East Timorese nationalism; but also, at times, to secure recognition of other identities that remain important to these actors, including local and 'traditional' forms of identity.

This 'recognition' dynamic has been evident in other political divisions since independence, such as those between 'diaspora' and 'local' independence movement figures; in intra-elite conflict between FRETILIN and non-FRETILIN members of the former 'united front' National Council of the Timorese Resistance (CNRT) (Leach 2006:233); and in the frequent gap between elite and popular values. For Trindade and Castro (2007:14), for example, a widely held

3 'Resolving Timor-Leste's crisis', p. 6, International Crisis Group. http://www.crisisgroup.org/ en/regions/asia/south-east-asia/timor-leste/120-resolving-timor-lestes-crisis.aspx (accessed 22-62012). [Asia Report 120.]

4 Later comments of José Ramos-Horta suggested that only 200 of the 600 had signed the petition alleging discrimination against westerners, and that the majority were younger soldiers aggrieved over the mistreatment and secondary status in relation to older, former FALINTIL veterans. This alternative perspective places the tension on the more familiar territory of intergenerational tensions in post-independence Timor-Leste. 
view across Timor was that 'the nation-state seems to benefit only the political elites ... which in turn come mainly from the eastern region that claimed to have fought more in the resistance and from the returned Timorese diaspora'. Some aspects of intergenerational tensions have also assumed the character of 'recognition' struggles since independence. These included the obvious issue of language policy, examined above, but also wider conflicts over the political and cultural dominance of older nationalists in post-independence political settlements. This extends to the comparative neglect of the youth-dominated civilian resistance in the national memorial landscape, compared with the greater public valorization of armed combatants of FALINTIL and senior FRETILIN and CNRT 'national heroes' (Leach 2009).

The link between deep-seated personal conflicts within Timor-Leste's small political elite and the regionalized voting blocs that emerged at the 2007 elections presents a particularly serious challenge to national integration. Where the eastern districts of Baucau, Lautem and Viqueque returned majorities for FRETILIN's presidential candidate, the districts around the capital (Dili, Manatuto and Liquica) became José Ramos-Horta's stronghold, and the western districts recorded their strongest votes for other opposition party leaders, such as Fernando 'Lasama' de Araujo of the Democratic Party (PD) or Xavier do Amaral of the Timorese Social Democratic Association (ASDT). With minor exceptions, ${ }^{5}$ this pattern was repeated in the parliamentary election in regionalized voting for FRETILIN, CNRT and ASDT or PD. In many cases, these results reflected the origins of party leaders in different language and ethnic groups, indicating the ongoing strength of regional political loyalties. Indeed, Kammen (2010:265) has argued that the post-2007 election map 'eerily mirrored' early Portuguese colonial perceptions of indigenous regional groupings on the eastern half of the island.

As such, while political divisions in Timor-Leste are more complex than a simple 'east-west' divide, there was a risk in the wake of the 2007 elections that FRETILIN as parliamentary opposition would primarily be seen to represent eastern districts, while the 'AMP' (Alliance with a Parliamentary Majority) coalition government will effectively be seen to represent the rest of the country. ${ }^{6}$ This presented a worrying potential for political 'balkanization' in Timor-Leste, and though the 2012 parliamentary elections saw some varia-

5 The 2007 exceptions were the western district of Covalima, which returned a slightly stronger Fretilin vote, and small CNRT leads in the western districts of Bobonaro and Oecussi. In 2012, all the western districts saw shifts in affiliations from smaller parties to CNRT, which finished first in nine of 10 'western' districts. Fretilin maintained its dominance of the three eastern districts, with a marginal lead in the neighbouring western district of Manufahi the sole exception to the regionalized division of leading parties.

6 'Timor-Leste's parliamentary elections', International Crisis Group. http://www.crisisgroup. org/en/regions/asia/south-east-asia/timor-leste/B065-timor-lestes-parliamentary-elections.aspx (accessed 22-6-2012). [Asia Briefing 65.] 
tion within the two regions, the overriding pattern of 'east-west' regionalized party affiliations remained intact. Another broad national integration issue was evident in the 2005 Church-backed protests over the question of religious education, which the former government had sought to make a voluntary component of the curriculum. These disturbances highlighted a broader conflict between the secularist orientation of important factions of the political leadership and the wider popular importance of Catholicism - and the power of the Church itself - in debates over 'national' values.

In sum, the power of 'resistance nationalism' (Anderson 1993) has been insufficient to sustain nation building in the face of serious post-independence political divisions and cultural fault lines. Even the memory of the 'mutual suffering $^{7}$ of the East Timorese people has become problematic as a potential integrating force, owing to the clear rift between popular and elite positions on the need for post-conflict justice. Dissatisfaction with the realpolitikinspired policies of reconciliation, rather than justice, towards the Indonesian military perpetrators and their militia proxies has fostered a deep legacy of unresolved popular resentment in Timor-Leste. ${ }^{8}$ And as Nicol (2002:337) presciently warned at independence, the ongoing strength of ethnic and regional loyalties would remain a potential tool to destabilize the nation and derail a nation-building agenda. In addition, an ongoing 'clash of paradigms' between traditional and modern democratic ideas of legitimacy in Timor-Leste is also widely considered to be an important issue for the stability of the nation-state as a whole. As Trindade and Castro (2007:14) have argued, many East Timorese

feel that they are lacking a sense of ownership of current governance processes. They mistrust the current government and perceive that the idea of the nationstate $[\ldots]$ is imposed on them just as the colonial system was.

Many of these national integration challenges were contributing factors in the political-military crisis of early 2006, and remain potential or latent sources of discord as the departure of the UN Integrated Mission in Timor-Leste (UNMIT) approaches in late 2012.

\section{Survey data: Tertiary student attitudes toward national identity in Timor-Leste}

In August 2002, July 2007, and March 2010 surveys of East Timorese tertiary students' attitudes towards national identity were undertaken in Dili. Some of

7 Ernest Renan 1882, cited in Borgerhoff (2006:109).

8 'Report of the Secretary-General on Timor-Leste pursuant to Security Council resolution 1690 (2006)', United Nations. http://daccess-dds-ny.un.org/doc/UNDOC/GEN/N06/448/33/PDF/ N0644833.pdf?OpenElement (accessed 25-6-2012). 
the questions were taken directly (with permission) from the ISSP module on National Identity; ${ }^{9}$ some new questions were added, and others were modified for this particular study to reflect local conditions, local and regional affiliations, and official languages. The survey was primarily fixed-question, and respondents were surveyed anonymously. All respondents in 2002 (n=320), 2007 $(n=250)$ and $2010(n=365)$ were tertiary students from the National University of Timor Lorosa'e (UNTL), University of Peace (UNPAZ), University of Dili (UNDIL) ${ }^{10}$ and Dili Institute of Technology (DIT), and they were 18 years of age or over. The surveys were translated into Indonesian, as this is still the written language that is most widely and easily understood, and importantly, it still remains a major medium of tertiary instruction. Questions fell into three broad categories: those addressing the respondents' gender, age, province of origin and self-identified language proficiencies; the (modified) core questions from the ISSP examining attitudes towards the relative importance of particular indicators of national identity, strength of affiliations to different levels of political community, national pride; and in the 2010 survey only, additional questions addressing issues and group loyalty indicators and preferences for agents of dispute resolution in differing circumstances. Together, these survey questions seek to provide insight in the attitudes of a (likely) future East Timorese elite.

Fixed 'language proficiency' questions gauged the respondents' self-identified level of fluency in the two 'official' (Tetum-Dili and Portuguese) and two 'working' (Indonesia and English) languages of the constitution. This question also allowed respondents to write in up to three other East Timorese languages they spoke, and to identify the level of fluency. A separate question at the end of the survey asked respondents to write in up to three languages spoken in the home. The modified set of ISSP questions then addressed subjective attitudes towards indicators of national identity, and national pride. Among other things, these indicators allow the researcher to assess the relative strength of civic or 'voluntarist' conceptions of national identity (which emphasize voluntary attachments to the nation, such as respect for political institutions and laws, or 'feeling' East Timorese); and ethnic or 'objectivist' understandings of national identity (which emphasize notions of common descent and culture, such as being born in Timor-Leste; being able to speak Tetum; or being Catholic). Most importantly, this methodology allows the researcher to investigate the extent to which institutionalized policies, collective mythologies and public discourses about national identity are reflected in the attitudes and beliefs of 'ordinary people'. ${ }^{11}$

9 http://www.issp.org/ (accessed 25-6-2012).

10 Though UNDIL is yet to receive full accreditation as a tertiary institution, it was operating as a private university at the time of each survey.

11 Jones and Smith 2001:47. As Borgerhoff (2006:103) notes, 'national building' can be understood as comprising two key elements: the strategies and policies of a nation-building elite, and resulting processes and impacts in the general population. 
Before outlining findings, it should be emphasized that these three survey groups cannot be considered 'representative' of East Timorese youth attitudes or language capacities. Rather, the study is a deliberate sample of tertiary students, which seeks to gauge the attitudes of an educated stratum, and one likely to contribute strongly to future political, economic and technocratic elites in Timor-Leste. ${ }^{12}$ However, as all but one of Timor-Leste's tertiary institutions are located in Dili, and students travel from all over the country to study, the three samples are nonetheless broadly representative of Timor-Leste's regions, comprising respondents from all 13 districts and various language groups. ${ }^{13}$

\section{Survey timing}

It is also useful to contextualize the timing of the three surveys. In August 2002, Timor-Leste had been independent for three months, following the formal handover from UNTAET on May 20. Prime Minister Mari Alkatiri led a new FRETILIN government, which had secured 55 of 88 seats in the Constituent Assembly elections in August 2001. Initially charged with drafting the constitution, the Constituent Assembly became the first National Parliament upon independence. At this time, the UN and other international presence in Dili was still at a peak.

By July 2007 the FRETILIN administration was in its final days. The 2007 elections took place in the tense wake of the 'east-west' crisis, with large numbers of internally displaced persons (IDPs) in and around Dili, an international presence of 1600 international police, and the Australian-led ISF military presence of 1000 troops. The 2006 crisis had resulted in 37 deaths and the displacement of over 100,000 people. Though no charges were ultimately laid against him, former Prime Minister Alkatiri had been forced to resign in June 2006 following allegations that Interior Minister Rogerio Lobato had armed a group of pro-FRETILIN civilians during the crisis. At the time of the survey in early July 2007, the parliamentary election results from June 30 were still unclear, though the presidential run-off vote in May (which saw José Ramos-Horta secure 69\%

12 It is worth noting that a small but significant group of scholarship students leave the country to study overseas. With the exception of those that study first at East Timorese institutions, this 'international' group is not sampled in these three surveys. Nonetheless, the domestic student population is a far larger group and, importantly for the purposes of this survey, more likely to be broadly representative of an 'educated stratum' of East Timorese youth attitudes. It is also notable that a significant percentage of the earliest groups of international students have not returned to Timor-Leste. For example, between 2001 and 2006, 127 East Timorese IPAD scholarship students undertook degrees in Portugal, but only 55 had returned as at 2011 (Queiroz 2011).

13 The survey asked students to identify their home district in Timor-Leste. Naturally, as in other settings, it cannot be assumed that tertiary students are socially or economically representative of the wider population. It should be noted, however, that access to tertiary education is by no means the marker of relative privilege it was in the Portuguese colonial era. 
of the vote against the FRETILIN candidate) indicated the strong likelihood of change. Former President Jose 'Xanana' Gusmao would shortly become Prime Minister, and form a coalition government of non-FRETILIN parties.

At the time of the third survey in March 2010, and despite the destabilizing attack on President Ramos-Horta in February 2008, Dili was experiencing a period of relative stability. The so-called 'east-west' tensions of $2006 \mathrm{had}$ passed by 2008, with urban life returning to relative normalcy, despite occasional eruptions of gang violence in the outer suburbs. The AMP government had been in office for some 30 months, and had expanded public works, introduced new aged pension schemes, provided heavily subsidized rice, and introduced a range of cash payments to address entrenched problems, including resettlement of most of the large numbers of IDPs resident in camps in Dili since 2006. These policies had clearly helped to secure peace, at least for the interim. On the other hand, there was episodic evidence of tensions within the governing alliance of parties, and the new administration was dogged by allegations of increasing corruption, with persistent - though at that time unproven - charges of large government contracts being awarded to relatives of ministers, without fully transparent tender processes (Dodd 2008).

\section{Survey findings}

\section{Self-identified language proficiency}

Percentage responses for the two official (Tetum-Dili and Portuguese), and two 'working' languages (Indonesian and English) are detailed in Tables 1a-c. It is important to emphasize that these are subjective indicators, testing only respondents' self-perceptions of fluency.

Table 1a. 2002 Self-identified language proficiency ( $\%$ of respondents; $n=320$ )

\begin{tabular}{lccccc}
\hline Language & Fluent & Moderate & Basic & None & No Response \\
\hline Tetum-Dili & 91.5 & 6 & 0.5 & 0 & 2 \\
Portuguese & 2.5 & 24 & 40 & 21.5 & 12 \\
Indonesian & 87 & 5.5 & 0 & 0 & 7.5 \\
English & 10 & 47 & 31 & 2 & 10 \\
\hline
\end{tabular}


Table 1b. 2007 Self-identified language proficiency (\% of respondents; $n=250$ )

\begin{tabular}{lccccc}
\hline Language & Fluent & Moderate & Basic & None & No Response \\
\hline Tetum-Dili & 94.5 & 3 & 0 & 0 & 2.5 \\
Portuguese & 8 & 52.5 & 23 & 3.5 & 13 \\
Indonesian & 84.5 & 8.5 & 0 & 0 & 7 \\
English & 8 & 51 & 23 & 4.5 & 13.5 \\
\hline
\end{tabular}

Table 1c. 2010 Self-identified language proficiency (\% of respondents; $n=365$ )

\begin{tabular}{lccccc}
\hline Language & Fluent & Moderate & Basic & None & No Response \\
\hline Tetum-Dili & 90 & 7.5 & 1.5 & 0 & 1 \\
Portuguese & 4.5 & 56.5 & 27 & 4.5 & 7.5 \\
Indonesian & 78.5 & 20 & 0.5 & 0 & 1 \\
English & 10 & 51 & 29.5 & 2.5 & 7 \\
\hline
\end{tabular}

As one would expect, East Timorese students identified the highest levels of fluency in Tetum-Dili and Indonesian. As might also be expected, there was a notable decrease in the percentage of students claiming fluency in Indonesian over the three surveys (from $87 \%$ to $78.5 \%$ ) with a slight decline in self-identified Tetum proficiency in 2010, possibly related to the emergence of a standardized - though contested - orthography for written Tetum, rather than as a vernacular oral medium. Across the three surveys, the rates of response for self-identified English language proficiency were quite consistent, reflecting both the status of English as global language (and its perceived associations with the promise of economic and social rewards), and the currency of the English language that has developed in the presence of large numbers of internationals in Dili since 1999.

By contrast, in 2002, those who identified as fluent $(2.5 \%)$ or moderate $(24 \%)$ speakers of Portuguese represented just over one-quarter of the sample. By 2007, however, though absolute levels of fluency were still low, there was a significant increase in respondents identifying as fluent in Portuguese (8\%), and more dramatically, in those identifying as moderately fluent, with over half the sample identifying in that category $(52.5 \%) .{ }^{14}$ In 2010 , the number identifying

14 Though measuring a specific group within the 'youth' demographic (tertiary students), these 2007 figures were broadly consistent with the 2004 national self-reported language capability statistics for 18 to 25-year-olds. Defining 'capable' as 'the capacity to speak, read or write or in any combination of the above', the national census found $36 \%$ of the population identified as 'capable' in Portuguese, with this figure rising to 51\% in the 18-25 demographic. The 2004 national census figures for capability among 18 to 25 -year-olds in Tetum (94\%), Indonesian (82\%) and English (42\%) were also broadly consistent when fluent and moderate speakers from the 
as 'fluent' speakers had moderated to $4.5 \%$, though the numbers identifying as 'moderate' speakers increased again to $56.5 \%$. This represented a very considerable jump in perceived levels of moderate fluency from the time of independence; though one that has experienced a 'plateau' since 2007. By contrast, English proficiency remained essentially static over the eight-year period.

\section{Languages spoken in the home}

These subjective self-perceptions of fluency are placed in an interesting context when compared with responses to the question concerning 'languages spoken at home' (see Table 2). Respondents were able to write in up to three languages, and large numbers (74\% 2002; 70\% 2007; 52\% 2010) did so - indicating that a majority regularly speak at least three languages in the home environment, though also demonstrating a decline in multi-language use since 2002.

Table 2. 'Constitutional' languages spoken in the home (\% of respondents)

\begin{tabular}{lccc}
\hline Language & 2002 & 2007 & 2010 \\
\hline Tetum-Dili & 92.5 & 94 & 94 \\
Portuguese & 11.5 & 23 & 15 \\
Indonesian & 56 & 43 & 37.5 \\
English & 8.5 & 10 & 12 \\
\hline
\end{tabular}

In each sample, well over $90 \%$ of respondents reported speaking at least some Tetum in the home environment, with Indonesian ranked a clear second. Here, in each sample, Portuguese displaced English as the third of the four official or working languages mentioned in the constitution. Back in 2002, where $8.5 \%$ identified speaking some English in the home environment, the figure for Portuguese was in this case higher at $11.5 \%$ of respondents. This was an important indicator, predating Portuguese language instruction in schools, suggesting that when communication patterns with older generations of family members in the home environment were taken into account, Portuguese had the stronger social base of the two European languages.

present sample were added, to approximate national census 'capability' criteria. The focus here on tertiary students likely accounted for the higher returns for Portuguese (61\%), Indonesian (still a major language of tertiary tuition - 98.5\%) and English (61\%). Comparable age-breakdown 'capability' figures from the 2010 census were not available at the time of writing, though national figures using the stricter 'literacy' definition (capacity to speak, read and write) for 15 to 24 -yearolds were Tetum 77.8\%, Portuguese 39.3\%, Indonesian 55.6\%, English 22.3\%. In 2004 these equivalent 'literacy' figures had been Tetum 68.1\%, Portuguese 17.2\%, Indonesian 66.8\%, English 10\% (Direcção Nacional de Estatística 2010, 2006; Taylor-Leech 2007). 
This tendency was markedly more exaggerated by 2007 - likely owing in part to the use of Portuguese (along with Tetum) in primary education - with $23 \%$ of respondents now reporting some use of Portuguese at home, against $10 \%$ for English. Here, the impact of language policy was most clearly evident. Importantly too, these figures are suggestive of the intergenerational divide over language. Clearly, any popularity of English among young people far outstrips the social importance of the language as a means of communication in the wider East Timorese society. By 2010 these two figures had narrowed again, with Portuguese again slightly higher, despite a decline in reported home usage from 2007.

Alongside these findings, these survey questions chart a marked decline $(18.5 \%)$ in students reporting usage of Indonesian in home environments over the eight-year period. By 2010, where 78.5\% reported being capable of using the language fluently, more than half did not exercise this capacity at home. Comparing reported individual fluency in the tertiary student age group against home language use is instructive in other areas. First, Tetum-Dili is clearly a cross-generational and unifying language, with parity between university student fluency levels and (cross-generational) home language use patterns. By contrast, Portuguese home usage exceeds tertiary student fluency rates in all three surveys, suggesting that the generations younger and older than the respondent group are the key sources of home use. English fluency matches with home use, suggesting this tertiary student group is likely to be the main source of any home usage. Qualitative interviewing supports this conclusion, suggesting inter-sibling communication is the primary source of any English language use in home environments.

Another integral part of the complex home language context is the ongoing importance of local Timorese languages. A strong majority of respondents listed a 'non-official' East Timorese language as one of up to three languages spoken in the home. In 2010, my sample of 365 revealed that $59 \%$ of respondents regularly spoke a language other than Tetum-Dili, Portuguese, Indonesian or English at home. However, this figure had dropped from 69\% in 2007, and $78 \%$ in 2002. These declining figures may reflect changing urban linguistic cultures within Dili, rather than a change in capacities, as home usage rates have declined more than reported fluency rates in non-official East Timorese languages, which remain strong (67\% of respondents in 2010 described themselves as 'fluent' in at least one East Timorese language other than Tetum-Dili, 63\% in 2007, 73\% in 2002). Overall, 19\% in 2010 identified a non-official East Timorese language as the first-listed language spoken at home (down from $20 \%$ in 2007, 26\% in 2002). 


\section{Responses to political community questions}

The survey also asked respondents to identify how close or 'emotionally attached' they feel to various levels of sub-national, national and supranational political community. A series of questions were asked to assess the relative depth of respondents' affiliations to their home neighbourhood (aldeia); to home sub-district, home district; nation; and finally, to the Southeast Asian region. The Melanesian region level was added to the 2010 survey (see Table 3c).

Table 3a. How close or emotionally attached do you feel to your ... (\% of respondents) $2002(n=320)$

\begin{tabular}{llllccc}
\hline & Very close & Close & $\begin{array}{c}\text { Total } \\
\text { close }\end{array}$ & $\begin{array}{c}\text { Not very } \\
\text { close }\end{array}$ & $\begin{array}{c}\text { Not close } \\
\text { at all }\end{array}$ & $\begin{array}{c}\text { Don't } \\
\text { know }\end{array}$ \\
\hline Home Aldeia & 42 & 41 & 83 & 12 & 3 & 2.5 \\
Home sub-district & 33 & 39.5 & 72.5 & 20 & 5.5 & 2 \\
Home district & 30.5 & 42.5 & 73 & 17.5 & 7 & 2.5 \\
Timor-Leste & 67 & 26 & 93 & 4 & 1.5 & 1.5 \\
Southeast Asia & 14.5 & 41.5 & 56 & 31 & 10 & 3 \\
\hline
\end{tabular}

Table 3b. How close or emotionally attached do you feel to your ... (\% of respondents) $2007(n=250)$

\begin{tabular}{llllccc}
\hline & Very close & Close & $\begin{array}{c}\text { Total } \\
\text { close }\end{array}$ & $\begin{array}{c}\text { Not very } \\
\text { close }\end{array}$ & $\begin{array}{c}\text { Not close } \\
\text { at all }\end{array}$ & $\begin{array}{c}\text { Don't } \\
\text { know }\end{array}$ \\
\hline Home Aldeia & 54 & 29 & 83 & 13 & 3.5 & 1 \\
Home sub-district & 38 & 37 & 75 & 19 & 5 & 1 \\
Home district & 39.5 & 39.5 & 79 & 15 & 5.5 & 0.5 \\
Timor-Leste & 67 & 23.5 & 90.5 & 6.5 & 1 & 2 \\
Southeast Asia & 20.5 & 30.5 & 51 & 36 & 10.5 & 2.5 \\
\hline
\end{tabular}

Table 3c. How close or emotionally attached do you feel to your ... (\% of respondents) $2010(n=365)$

\begin{tabular}{lcccccc}
\hline & Very close & Close & $\begin{array}{c}\text { Total } \\
\text { close }\end{array}$ & $\begin{array}{c}\text { Not very } \\
\text { close }\end{array}$ & $\begin{array}{c}\text { Not close } \\
\text { at all }\end{array}$ & $\begin{array}{c}\text { Don't } \\
\text { know }\end{array}$ \\
\hline Home Aldeia & 38.5 & 41 & 79.5 & 16 & 4 & 0.5 \\
Home sub-district & 25 & 38 & 63 & 27.5 & 9 & 1 \\
Home district & 24.5 & 38 & 62.5 & 28 & 9 & 0.5 \\
Timor-Leste & 55 & 37.5 & 93.5 & 6.5 & 1 & 0 \\
Southeast Asia & 13 & 39 & 52 & 31 & 13.5 & 3.5 \\
$\begin{array}{l}\text { Melanesian region } \\
\text { (2010 only) }\end{array}$ & 6 & 14 & 20 & 34.5 & 31 & 14.5 \\
\hline
\end{tabular}


Interesting continuities and differences are evident in the three time-sequenced surveys. First, degrees of total closeness were relatively consistent over time, with one important exception: degrees of total closeness to sub-district and district spiked moderately in 2007, before dropping considerably by 2010. This may indicate a drop in the social legitimacy of these (sub-national) identifications by 2010 (in the wake of the 2006-7 violence and dislocation), or, potentially, the progressive growth of an urbanized culture within Dili, more dislocated from its rural origins. Second, in terms of intensity, it is likewise notable that reports of feeling 'very close' to all sub-national levels of affiliation peaked strongly in the 2007 survey. Overall, each of the three surveys indicates the relative strength of neighbourhood (aldeia) and national affiliations, when compared with other affiliations. Finally, the 2010 survey clearly demonstrates the relative strength of Southeast Asian affiliation (52\%) among tertiary students relative to any affinity they feel to the Melanesian societies further east (20\%). This is an interesting finding which casts light on tertiary student perceptions of the view, more frequently expressed before independence, that Timor-Leste may be seen as a 'crossroads' society, linking Southeast Asia with the Pacific-Melanesian region. ${ }^{15}$

\section{Closeness to other countries}

The findings on supranational affiliations were supported in 2010 by a new question assessing feelings of closeness to other countries, presented in Table 4. Respondents reported the strongest feelings of closeness to the two countries of greatest regional influence - Indonesia (89\%), and Australia (69\%) with the next highest responses for the two Southeast Asian countries with the highest levels of state-building involvement in Timor-Leste - Malaysia (34\%) and the Philippines (30.5\%). Next in terms of feelings of closeness was former colonial power and state-building partner Portugal (28.5\%), which rated third behind Indonesia and Australia in terms of respondents feeling 'very close'. With the exception of West Papua and Papua New Guinea, Melanesian countries fared poorly. Other countries rating reasonably highly included the state-building partners Brazil, Japan and Cuba. Despite its high profile aid donations and building programme, China was rated lower, at 15.5\%, though this figure was higher than its traditional competitor in relation to small island nations, Taiwan.

15 Ramos-Horta 1996. As José Ramos-Horta expressed it in his Nobel Lecture, 'East Timor is at the crossroads of three major cultures: Melanesian, which binds us to our brothers and sisters of the South Pacific region; Malay-Polynesian binding us to South East Asia, and the Latin Catholic influence, a legacy of almost 500 years of Portuguese colonization'. 
Table 4. How close or emotionally attached do you feel to ...? (\% of respondents) 2010 ( $\mathrm{N}$ varies)

\begin{tabular}{lcccccc}
\hline & Very close & Close & $\begin{array}{l}\text { Total } \\
\text { close }\end{array}$ & $\begin{array}{c}\text { Not very } \\
\text { close }\end{array}$ & $\begin{array}{c}\text { Not close } \\
\text { at all }\end{array}$ & $\begin{array}{c}\text { Don't } \\
\text { know }\end{array}$ \\
\hline Indonesia & 49.5 & 39.5 & 89 & 9.5 & 1 & 0.5 \\
Australia & 27.5 & 41.5 & 69 & 20.5 & 6 & 3.5 \\
Malaysia & 7.5 & 26.5 & 34 & 44.5 & 16 & 5 \\
Philippines & 6 & 24.5 & 30.5 & 44 & 19 & 6.5 \\
Portugal & 10 & 18.5 & 28.5 & 35 & 35 & 1.5 \\
West Papua & 7.5 & 18.5 & 26 & 38 & 26.5 & 9 \\
PNG & 6 & 16.5 & 22.5 & 36 & 29.5 & 12 \\
UK & 5.5 & 17 & 22.5 & 29.5 & 42 & 6 \\
Brazil & 6.5 & 15.5 & 22 & 32 & 40.5 & 5.5 \\
Japan & 4.5 & 17.5 & 22 & 35 & 35.5 & 7.5 \\
USA & 6 & 15 & 21 & 27.5 & 44.5 & 6 \\
Cuba & 7 & 13 & 20 & 30.5 & 42.5 & 7 \\
New Zealand & 4.5 & 14 & 18.5 & 32 & 38 & 11.5 \\
Mozambique & 3.5 & 12.5 & 16 & 32.5 & 42.5 & 9 \\
China & 2.5 & 13 & 15.5 & 41 & 24.5 & 9 \\
Taiwan & 3.5 & 8.5 & 12 & 35 & 42 & 11 \\
Fiji & 2.5 & 8 & 10.5 & 32 & 40 & 17.5 \\
Solomon Islands & 2.5 & 4 & 6.5 & 32.5 & 38 & 23 \\
Vanuatu & 3 & 3.5 & 6.5 & 31 & 38.5 & 24.5 \\
New Caledonia & 2 & 4 & 6 & 28 & 42 & 24 \\
\hline
\end{tabular}

\section{Attitudes toward national identity}

The survey then asked respondents about the importance of certain attributes or attitudes to being 'truly East Timorese'. The national identity module consists of the following eight questions. Respondents rated their responses to these questions as 'very important'/'important'/'not very important'/or 'not at all important.' Responses are tabulated in Tables 5a-c.

Some people say the following things are important for being truly East Timorese. Others say they are not important. How important do you think each of the following is?
a. To have been born in Timor-Leste?
b. To have East Timorese citizenship?
c. To have lived in Timor-Leste for most of one's life?
d. To be able to speak Tetum?
e. To be able to speak Portuguese? 

f. To be a Catholic?
g. To respect tradition and adat
h. To respect Timor-Leste's political institutions and laws?
i. To feel East Timorese?

In 2002, responses to the two language-related questions in the national identity module revealed a stark contrast with respect to the two official languages. Where $83 \%$ of respondents described 'ability to speak Tetum' as 'very important to being truly East Timorese'; the equivalent figure for Portuguese was $24 \%$. Indeed, 'ability to speak Portuguese' was by far the most controversial indicator among East Timorese tertiary students (see Table 5a). Compared with all other indicators of ethnic and civic national identity in 2002, the challenges to the advocates of Portuguese were evident.

Table 5a. 2002 national identity module responses (\% of respondents; $n=320$ )

\begin{tabular}{lcccc}
\hline Indicator & Very important & Fairly important & Not very important & Not at all important \\
\hline Born in ET & 90 & 5 & 3.5 & 1 \\
Citizen of ET & 90.5 & 5 & 3.5 & 1 \\
Lived in ET & 59.5 & 14.5 & 22 & 4 \\
Speak Tetum & 83 & 9 & 7 & 1 \\
Speak Portuguese & 24 & 31 & 26.5 & 17 \\
Be Catholic & 81 & 5.5 & 9.5 & 2 \\
Respect Law & 89.5 & 5 & 3.5 & 0.5 \\
Feel ET & 84.5 & 7 & 5 & 1.5 \\
\hline
\end{tabular}

From 2007 this picture had changed dramatically (see Table 5b; Figures 1a and $1 \mathrm{~b}$ below). Where $88.5 \%$ ( $+5.5 \%$ ) of respondents now described 'ability to speak Tetum' as 'very important to being truly East Timorese'; the equivalent figure for Portuguese was now substantially higher at 52\% (+28\%). In 2010, this figure had stabilized, again at $52 \%$. While 'ability to speak Portuguese' remained a comparatively controversial indicator among East Timorese tertiary students, a majority of respondents now described it as 'very important to being truly East Timorese', with a further $28 \%$ regarding it as 'important' in 2007 , rising to $31 \%$ in 2010 . Accordingly, the percentage of students regarding Portuguese as 'not very' or 'not at all important' to being 'truly East Timorese' had more than halved from $43.5 \%$ in 2002 , to $20 \%$ in 2007 , and then dropped to $14.5 \%$ by 2010 . The latter figure on 'overtly negative' responses to the official status of Portuguese accords with qualitative research done in this age group (Taylor-Leech 2008:171). 
Table 5b. 2007 national identity module responses (\% of respondents; $n=250$ )

\begin{tabular}{lcccc}
\hline Indicator & Very important & Fairly important & Not very important & Not at all important \\
\hline Born in ET & 94.5 & 4.5 & 1 & 0 \\
Citizen of ET & 93 & 5 & 2 & 0 \\
Lived in ET & 56.5 & 18.5 & 21.5 & 3.5 \\
Speak Tetum & 88.5 & 7.5 & 3.5 & 0.5 \\
Speak Portuguese & 52 & 28 & 14 & 6 \\
Be Catholic & 84 & 7 & 8 & 1 \\
Respect Law & 92 & 7.5 & 0.5 & 0 \\
Feel ET & 91 & 8 & 1 & 0 \\
\hline
\end{tabular}

Table 5c. 2010 national identity module responses (\% of respondents; $n=365$ )

\begin{tabular}{lcccc}
\hline Indicator & Very important & Fairly important & Not very important & Not at all important \\
\hline Born in ET & 94.5 & 3.5 & 0.5 & 0 \\
Citizen of ET & 95.5 & 3 & 1 & 0.5 \\
Lived in ET & 60.5 & 18 & 17.5 & 1.5 \\
Speak Tetum & 88.5 & 8.5 & 2.5 & 0 \\
Speak Portuguese & 52 & 31 & 12.5 & 2 \\
Be Catholic & 78 & 11 & 8 & 1 \\
Respect Adat & 93.5 & 4.5 & 1 & 0.5 \\
Respect Law & 92.5 & 6 & 1 & 0.5 \\
Feel ET & 88.5 & 7.5 & 2 & 1 \\
\hline
\end{tabular}

As I have argued in previous studies, examining the intergenerational fault lines that emerged in the early years after independence (Leach 2003, 2008), the distinct experiences and educational backgrounds of two generations of nationalists, respectively encountering Portuguese and Indonesian colonialism, complicated the task of articulating a simple, unifying post-colonial national identity after independence. Specifically, in 2002, there was an apparent and distinctive intergenerational rupture in an 'official' narrative emphasizing affiliations to Portuguese language and cultural heritage. By 2007 tensions over this issue were still evident, but in a substantially less volatile register. As is evident in Figure 1b, this apparent shift had stabilized at a similar level in the 2010 survey. ${ }^{16}$

16 After independence, the 'Indonesia generation', aged between 25 and 40 and educated in Indonesian, had legitimate concerns about their potential exclusion from government jobs and other forms of social and economic participation in the new state. With the passage of time, however, these issues have become more complex than 'younger versus older' people. While some $75 \%$ of East Timorese are under 30 years of age, a full $50 \%$ of the population is under 15 . As such, the 'Indonesia generation' have their own equivalent of 'generation $Y$ ' behind them - a much larger group, many of whom could turn out to be competent Portuguese speakers, depending on the ongoing language policy and educational environment. See Leach 2008. 
Figure 1a. Attitudes to Tetum language, 2002-2010

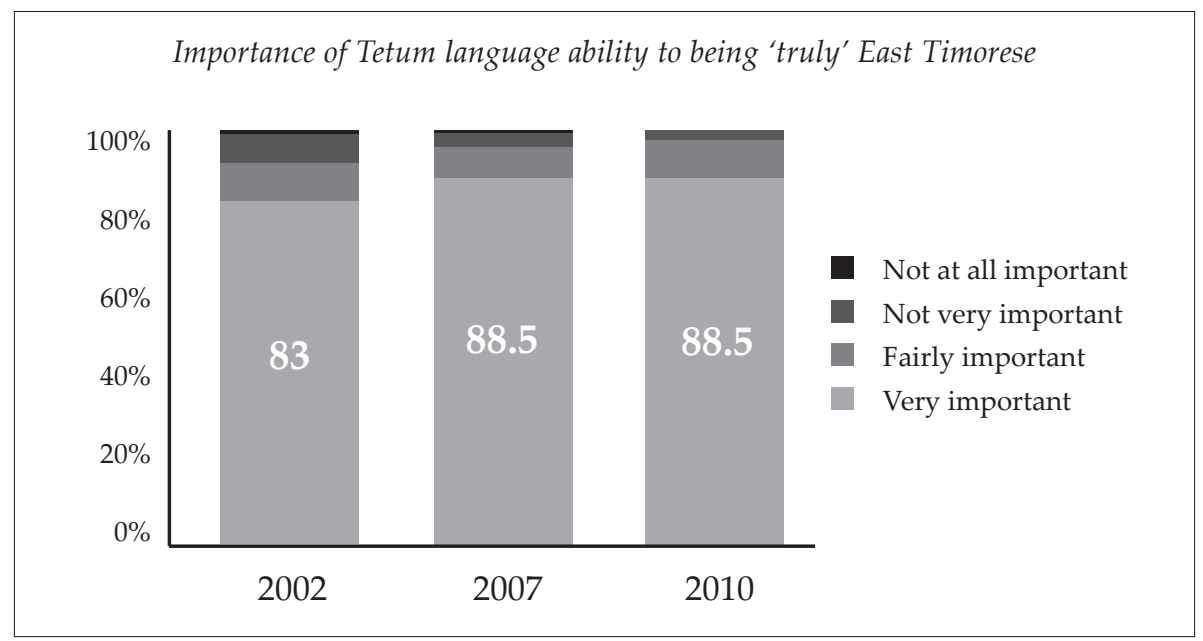

Figure 1b. Attitudes to Portuguese language, 2002-2010

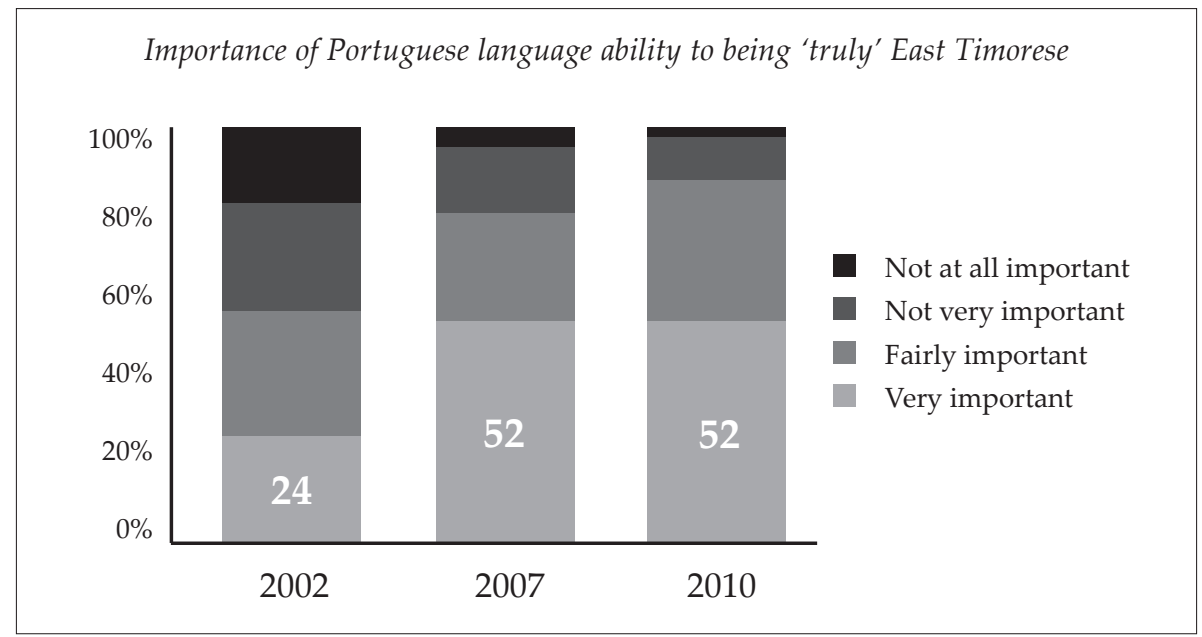

Correlations between language proficiency and attitudes to national identity

Cross-tab analyses between responses on language fluency and particular attitudes toward language and national identity support the hypothesis that mixed cultural and linguistic identifications may inform divergent understandings of national identity. Unsurprisingly, in all three samples, there is 
a very strong positive correlation between Portuguese language fluency, and attitudes towards the importance of Portuguese language to being 'truly East Timorese' ${ }^{17}$ Fluent and moderate speakers of Portuguese were far more likely to rate the ability to speak Portuguese as 'very important' to being East Timorese than those with basic or no fluency in Portuguese. This relationship was again found in 2007 and 2010, with a strong correlation surviving the increase in overall percentages of fluent and moderate Portuguese speakers. ${ }^{18}$

\section{Attitudes to Catholicism}

Despite the controversy over Portuguese language in 2002, other aspects of Portuguese cultural heritage were subject to a high degree of consensus. In particular, 'being Catholic' was rated as 'very important' to being 'truly' East Timorese by $83 \%$ of respondents (84\% in 2007, declining to $78 \%$ in 2010). The high level of consensus around Catholicism as an important indicator of national identity suggests that this element of Portuguese colonial heritage is well integrated into the East Timorese sense of self. Indeed, for most young East Timorese, it is probably no longer strongly associated with Portuguese colonialism, but rather, as noted further below, with cultural resistance to the Indonesian occupation. The Church's decision to use Tetum rather than Indonesian in services reinforced the language's status as a lingua franca in parts of East Timor, facilitating its emergence as a distinctly 'national' language and expression of national identity. As former Minister Armindo Maia noted in 2002, before 1975, Tetum-Dili was used by 'less than $30 \%$ of the people ... but then the priests decided to use Tetum' ${ }^{19}$ At the same time, the role of the Church as a unifying forum for expressing the common suffering of various ethnic and language groups in East Timor greatly increased its popularity, and to some degree made Catholicism itself a salient expression of national identity during the occupation. ${ }^{20}$ Reflecting these nation-building roles, the Catholic Church received a special mention in the 2002 constitution, valorized by the State for its 'participation ... in the process of national liberation of East Timor' (s11.2). It is notable, however, that there was a decline in tertiary students' ratings over the eight-year period, perhaps reflecting a degree of con-

17 Using SPSS crosstab analysis, a chi-square test established significance at $<0.1 \%$ (where $5 \%$ is a statistically significant correlation). Chi-square tests indicate the significance of association between qualitative variables.

18 Chi-square test established significance at $<0.4 \%$ (where $5 \%$ is a statistically significant correlation).

19 Interview with author, 13 August 2002.

20 Anderson 1993. As Anderson notes, the Indonesian state requires citizens to affiliate to one of the five official religions. Thus, while mistrusting the spread of Catholicism in East Timor - particularly as the local Church remained staunchly independent of the Indonesian Catholic hierarchy - the logic of the state also demanded it. 
troversy attending the Church's more frequent involvement in politics over recent years, and in particular, its involvement in anti-government protests in 2005 over issues such as civil registration and religious education in schools.

\section{Importance of adat}

A new question, first posed in the 2010 survey, asked students how important 'to respect tradition and adat' was to being 'truly East Timorese'. Despite the evident importance of Catholicism to perceptions of national identity, it is revealing that 'respect for tradition and adat' exceeded this indicator by some $15 \%$ as a 'very important' attribute of being 'truly East Timorese' (93.5\%). That this finding reflects the perceptions of one of the most educated, urbanized and 'modern' segments of East Timorese society amply demonstrates the ongoing strength of traditional conceptions of political community and identity in Timor-Leste.

\section{National pride indicators}

In 2002, the survey offered survey evidence to support the view that constitutional affiliations to Portuguese language could be considered a strongly 'disputed narrative' of national identity in Timor-Leste. Though it still remained relatively controversial (in relation to other indicators of national identity) in the second and third surveys, a significant shift in the attitudes of the target group was evident by 2007, and had maintained this level in 2010 despite a decrease in reported language fluency and home use.

However, other 'official' narratives of national identity in Timor-Leste accorded more strongly with 'popular' attitudes, across the three samples. In particular, the constitutional emphasis on 'valorizing the resistance' appeared to resonate strongly with the views of tertiary students as a key narrative of national history and identity (Leach 2003). Notably, national identity module questions about respondents' levels of national pride suggest the relative strength of narratives about East Timorese history (see Tables 6a-c), which emerged as the most 'undisputed' object of national pride for East Timorese tertiary students in the three samples.

Notably, all areas of national pride had suffered a decrease over the 20022007 survey period, with the exception of pride in East Timorese culture. In particular, the legacies of the 2006 political crisis - of the 'east-west' violence, the dislocation of over 100,000 Dili residents in IDP camps, and the resignation of Prime Minister Alkatiri - were clearly evident in the dramatic decline in respondents' pride in 'the way democracy works' $(-15 \%)$, and in TimorLeste's 'fair and equal treatment of all groups in society' $(-17.5 \%)$. 
By the time of the 2010 survey, pride in democracy had experienced a partial recovery ( $45.5 \%$ 'very proud'), though not to 2002 levels. While pride in East Timorese history also recovered over the 2007-10 period, pride in the 'fair and equal treatment of all groups in society' remained essentially static, showing no signs of improvement from the low level recorded in 2007

Table 6a. 2002 national pride responses (\% of respondents; $n=320$ )

Q: How proud are you of Timor-Leste in each of the following?

\begin{tabular}{lccccc}
\hline & Very proud & Proud & $\begin{array}{c}\text { Not very } \\
\text { proud }\end{array}$ & $\begin{array}{c}\text { Not at all } \\
\text { proud }\end{array}$ & $\begin{array}{c}\text { Don't know/ } \\
\text { No response }\end{array}$ \\
\hline The way democracy works & 51 & 28 & 17 & 2 & 2 \\
Its distinctive culture & 70 & 24 & 4 & 0 & 2 \\
Timor-Leste's history & 81 & 15.5 & 2 & 0.5 & 1 \\
$\begin{array}{l}\text { Its fair and equal treatment } \\
\text { of all groups in society }\end{array}$ & 67.5 & 20.5 & 10 & 1.5 & 0.5 \\
\hline
\end{tabular}

Table 6b. 2007 national pride responses (\% of respondents; $n=250$ )

Q: How proud are you of Timor-Leste in each of the following?

\begin{tabular}{lccccc}
\hline & Very proud & $\begin{array}{c}\text { Proud } \\
\text { Nhe way democracy works }\end{array}$ & $\begin{array}{c}\text { Not very } \\
\text { proud }\end{array}$ & $\begin{array}{c}\text { Not at all } \\
\text { proud }\end{array}$ & $\begin{array}{c}\text { Don't know/ } \\
\text { No response }\end{array}$ \\
\hline Th distinctive culture & 69 & 33 & 22 & 7 & 2 \\
Timor-Leste's history & 76 & 22 & 5 & 0 & 1 \\
$\begin{array}{l}\text { Its fair and equal treatment } \\
\text { of all groups in society }\end{array}$ & 50 & 27.5 & 17 & 3 & 0.5 \\
\hline
\end{tabular}

Table 6c. 2010 national pride responses (\% of respondents; $n=365$ )

Q: How proud are you of Timor-Leste in each of the following?

\begin{tabular}{lccccc}
\hline & Very proud & Proud & $\begin{array}{c}\text { Not very } \\
\text { proud }\end{array}$ & $\begin{array}{c}\text { Not at all } \\
\text { proud }\end{array}$ & $\begin{array}{c}\text { Don't know/ } \\
\text { No response }\end{array}$ \\
\hline The way democracy works & 45.5 & 34 & 18 & 2 & 0.5 \\
Its distinctive culture & 67 & 29 & 3.5 & 0.5 & 0.5 \\
$\begin{array}{l}\text { Timor-Leste's history } \\
\text { Its fair and equal treatment }\end{array}$ & 80 & 17.5 & 2 & 0.5 & 0 \\
of all groups in society & 48.5 & 28 & 18.5 & 4 & 1 \\
\hline
\end{tabular}




\section{'Regional' differences in tertiary student attitudes}

As already noted, the initial phases of the 2006 political-military crisis were routinely characterized as a conflict between 'easterners' and 'westerners' within Dili. The three surveys reveal very few significant differences in attitudes between tertiary students from eastern and western districts, though the particular exceptions are revealing, and strongly support the view that these conflicts were the political by-products of disputes within the East Timorese political elite, and intimately connected to conflict patterns resulting from increased rural-urban migration to Dili. In particular, these were associated with popular resentment over returning 'diaspora' political elites gaining power, and reactions - whether accurate or otherwise - to their perceived favouring of particular 'regions'. As this series of surveys has recorded respondents' home districts since 2002, it is in a position to track any significant differences in attitudes between East Timorese students originating in the three 'eastern' districts, and the remaining 10 'western' districts.

Instructively, the 2002 surveys revealed no significant differences in attitudes when disaggregated by 'region' of origin. This is an important base indicator highlighting the impact of subsequent years, and the 2006 crisis, on tertiary student attitudes. In the 2007 survey, however, in the wake of political-military crisis and the politicization of regional identity, certain indicators revealed significant differences when disaggregated by 'region'. The most striking of these was the perceived importance of having 'lived in TimorLeste all of one's life' as an indicator of being 'truly East Timorese' (see Table 7). Here a dramatic difference between the views of students from eastern and western districts was evident, which linked clearly with popular resentment over the perceived rewards of government falling to East Timorese who had spent the occupation years outside the country. Though all major factions of East Timorese politics had key leadership figures in this category, in 2007 this was viewed as a key charge against the FRETILIN government, and was particularly associated with figures such as Rogerio Lobato who had spent time in Mozambique. The impact of these perceptions is clearly evidenced below. Though this was overall one of the least supported measures of being 'truly East Timorese', students from western districts (82.5\% total agree) were far more likely to agree that this was an important indicator than those from eastern districts (60.5\% total agree). ${ }^{21}$ This finding clearly suggests the accusations that a 'diaspora' group dominated the then FRETILIN government (and favoured easterners for government and senior army positions) resonated more profoundly among students from the western districts. 
Table 7. Importance of having 'lived in Timor-Leste most of one's life' to being 'truly East Timorese' ( $\%$ by 'region', 2007, $\mathrm{n}=250$ )

\begin{tabular}{lcccccc}
\hline & $\begin{array}{c}\text { Very } \\
\text { important }\end{array}$ & $\begin{array}{c}\text { Fairly } \\
\text { important }\end{array}$ & $\begin{array}{c}\text { Total } \\
\text { important }\end{array}$ & $\begin{array}{c}\text { Not very } \\
\text { important }\end{array}$ & $\begin{array}{c}\text { Not at all } \\
\text { important }\end{array}$ & $\begin{array}{c}\text { Don't } \\
\text { know }\end{array}$ \\
\hline Eastern districts & 40 & 20.5 & 60.5 & 33.5 & 6 & 0.7 \\
Western districts & 65 & 17.5 & 82.5 & 15.5 & 2 & 1.0 \\
\hline
\end{tabular}

In 2007, this finding was reinforced by other data which likewise reflected the patterns of urban conflict within Dili, rather than a wider 'ethnic' division of any sort. For example, students from eastern districts - at a time when 'easterners' dominated displaced residents of the IDP camps in Dili - expressed lower degrees of pride in 'the fair and equal treatment of all groups in society' (72\%) than did students from western districts $(81 \%)$.

By 2010, the findings were far less stark, reflecting both the diminution of regional tensions since 2006-7, and a shift in conflict patterns to interneighbourhood conflicts based on family groups, and frequently involving martial arts connections (Scambary 2009). The few findings in 2010 which showed any significant difference based on 'region' of origin were limited to issues clearly rooted in the urban politics of Dili (see Figure 2). ${ }^{22}$ These reflected the perception among some Dili residents from western districts that the capital is located in the 'west', giving easterners less legitimate claims to ownership of potentially contested urban areas. For example, a higher proportion of students from western districts (35\%) strongly agreed with the proposition that 'people moving to the cities cause social problems' than students from eastern districts (27\%). Likewise, the proposition that 'people should stay in the areas where they grew up' attracted stronger support from westerners $(28.5 \%)$ than from easterners $(19 \%)$ who were, accordingly, more likely to strongly disagree with both propositions. Another notable finding was that students from eastern districts expressed higher degrees of closeness to Portugal (36\%) than did students from western districts (25\%). This finding - inconsistent with other measures such as the importance of speaking Portuguese, or ability to speak Portuguese, which showed no regional differences - is possibly related to patterns of post-crisis policing in Dili, and the reported perceptions, accurate or otherwise, among 'eastern' residents of Dili that the Portuguese Republican Guard (GNR) was the more neutral of the international policing forces in their dealings with easterners; though it

22 The sole issue that might be interpreted more widely is the finding that students from the eastern districts are more likely to oppose foreigners buying land (78\%) than students from the western districts $(65 \%)$. This may reflect the fact that the eastern districts are less historically integrated into commodity production for international trade, with coffee and other export plantations almost exclusively located in western districts (see Matsuno 2010). 
may also have derivatively reflecteed regionalized political party affiliations between FRETILIN- and PD-oriented students. ${ }^{23}$

Figure 2. Attitudes to urban-rural migration, by 'region' of origin, $2010(n=365)$

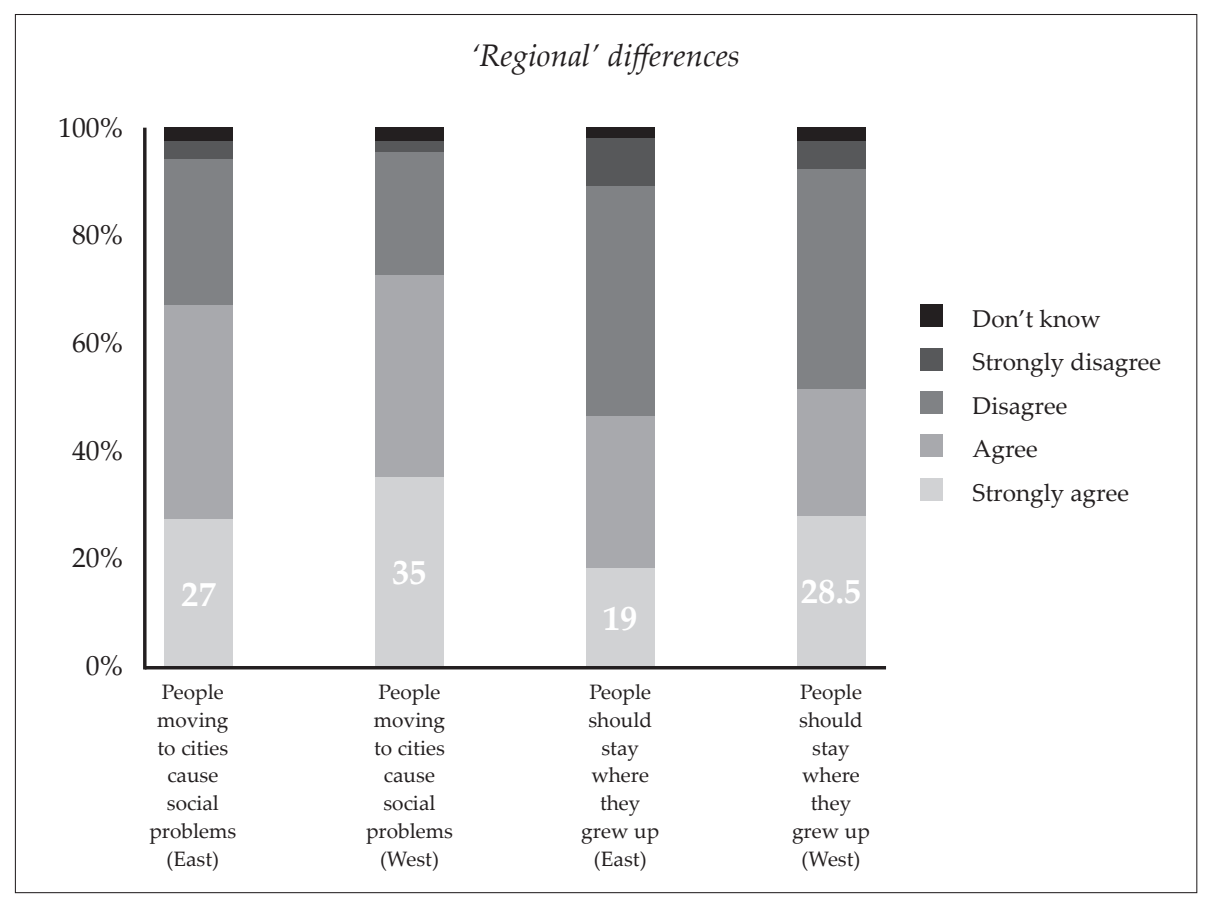

Responses to dispute resolution questions

The ongoing importance of both traditional and modern understandings of political community was evident in a set of questions concerning student preferences for agents of dispute resolution. Depending on the nature of the dispute, student responses varied significantly between traditional and modern domains. Reflecting the continuing strength of traditional authorities in the rural areas of Timor-Leste, responses to the question of 'who should resolve

23 It is often reported that East Timorese universities have particular political party affiliations, though there is also evidence of some links diminishing since the early years of independence. While it is unclear whether students themselves ever shared such party affiliations, it is clear that some tertiary enrolment patterns are nonetheless associated with 'region' of origin. For example, students from eastern districts were at one time less likely to enrol at UNPAZ, located in an area of Dili which became difficult for easterners in 2006-7. This study found no strong associations between institutional affiliation and attitudes per se, except insofar as these reflected the small number of 'region of origin' associations discussed above. 
disputes between neighbours' revealed that $47 \%$ of students favoured traditional authorities and elders, where 39\% favoured the modern state alternative of the national police, with a further $12 \%$ choosing international police. By contrast, support for traditional authorities in resolving 'disputes over land' was much lower, with $28 \%$ favouring traditional leaders, and $58 \%$ favouring the national government. These responses reflect the complicated overlay of successive traditional, Portuguese and Indonesian land titles that have been an ongoing source of conflict since independence, particularly within Dili. Despite the traditional role of Liurai and Lia Na'in in mediating such matters in rural areas, land title is now widely regarded to be an issue that must be addressed centrally by the national government.

In cases of crimes against the person, and crimes against property, students' responses indicated clear preferences for modern agents of dispute resolution. These responses also highlighted student attitudes towards international state-building assistance, in the form of United Nations Police (UNPOL) and the International Stabilization Force (ISF). In general, responses indicated a relatively high level of confidence in the national police, suggesting a restoration of confidence in the force which collapsed in the 2006 political-military crisis. When asked 'who should resolve crimes against property?', student respondents overwhelmingly favoured the national police $(77 \%)$, with $12 \%$ supporting traditional authorities and elders, and $10 \%$ selecting international police. Importantly, however, when asked 'who should resolve crimes against the person?', respondents returned a relatively higher rate for international police (national police $74 \%$, international police $17 \%, 7 \%$ traditional authorities and elders). While on the one hand this finding reflects longstanding traditions of referring certain 'blood crimes' to the state rather than traditional authorities, it also has potential ramifications in the planning beyond the full withdrawal of international policing forces in late 2012, with the role of external forces having had relatively more support in relation to offences against the person. There were no significant regional differences with regard to these questions.

\section{Gender breakdown: Preferences for dispute resolution}

The findings also indicated significant gender differences in preferences for dispute resolution, particularly in relation to the role of traditional authorities and elders. Where $52 \%$ of male respondents indicated a preference for traditional authorities to address disputes between neighbours, for female respondents it was substantially lower at $41 \%$. Female students also expressed significantly lower preferences for traditional authorities to resolve disputes over land (33\% male, $21 \%$ females). These findings indicate that educated female students are more likely to question male-dominated traditional hierarchies 
in the villages, which reflects the lack of adequate opportunities for women's participation and representation in traditional decision-making processes. As Cummins (2011:86) notes, despite having reserved positions on suco councils (local government), and good representation at the national parliamentary level (27.7\% of seats), the number of women suco chiefs totals a mere 11 out of $442(2.48 \%)$. Women face a number of structural barriers to participation at local government level, where the cooperation of traditional leaders is critical to effective modern leadership, and traditional conceptions of political authority and cultural norms of dispute resolution mitigate against women's representation (Cummins 2011:92).

\section{Responses to group identification question}

Respondents were asked to rank the top three groups with which they identified most strongly. In effect, this question allowed students to rank order the importance of some potentially available communal identities. Table 8 lists the first preference responses regarded as 'most important', and also rank orders their combined top three preferences. The findings demonstrate the primary importance (in both first preference and combined rank order) of occupation, family, and religion to East Timorese tertiary students. Sub-national identities were of lower importance, though it is notable that $40 \%$ of respondents listed 'language group' among their top three responses, with nearly a quarter separately listing the 'region of the country you live in'.

Table 8. We are all part of different groups, but some are more important than others to us. Which do you rate as the most important? 2010 (n=365, \%).

\begin{tabular}{lcccc}
\hline Group & $\begin{array}{c}\text { Most } \\
\text { important }\end{array}$ & $\begin{array}{c}\text { Second most } \\
\text { important }\end{array}$ & $\begin{array}{c}\text { Third most } \\
\text { important }\end{array}$ & Combined \\
\hline Occupation & 36.5 & 20 & 18.5 & 75 \\
Family & 22.5 & 12.5 & 24 & 59 \\
Religion & 11.5 & 26 & 15.5 & 53 \\
Language group & 8 & 22.5 & 9.5 & 40 \\
Nationalist & 9.5 & 12 & 16.5 & 38 \\
Region of the country you live in & 6.5 & 5 & 11.5 & 23 \\
Gender & 4 & 1 & 1 & 6 \\
Preferred political party & 0.5 & 0.5 & 3 & 4 \\
Age & 1 & 1 & 0.5 & 2.5 \\
\hline
\end{tabular}

A further question later in the survey sought to elicit data about perceptions of obligations or loyalties to different levels of community. Respondents were asked to rank the top three loyalties from among district, language group, fam- 
ily, nation and village. Table 9 lists the first preference responses regarded as 'most important', and also rank orders their combined top three preferences. This question elicited slightly different responses, with family, and then district, preceding the nation as the 'most important' locus of obligation or loyalty. While 'nation' was the second most commonly mentioned loyalty overall (65.5\% listed it as one of their three preferences) after family (79.5\% across three preferences), the largest share of these were third preferences (31.5\%), demonstrating that in concentric circles of obligation, nation rarely features foremost.

Table 9. We all feel we have obligations or loyalties to different groups. But some are stronger than others. Which do you rate as the most important? 2010 ( $n=365, \%)$

\begin{tabular}{lcccc}
\hline Group & $\begin{array}{c}\text { Most } \\
\text { important }\end{array}$ & $\begin{array}{c}\text { Second most } \\
\text { important }\end{array}$ & $\begin{array}{c}\text { Third most } \\
\text { important }\end{array}$ & Combined \\
\hline Family & 38 & 24.5 & 16.5 & 79.5 \\
Nation & 18 & 16 & 31.5 & 65.5 \\
District & 22.5 & 13 & 19 & 54.5 \\
Language group & 12.5 & 26 & 13 & 51.5 \\
Village & 9 & 20 & 20 & 49 \\
\hline
\end{tabular}

\section{Student assessments of state building and development priorities}

As noted above, while state and nation building should be regarded as conceptually distinct activities, state-building activities inevitably constitute an important subset of nation-building agendas. A further set of questions was included in the survey to identify the most important activities that could 'build the nation of Timor-Leste'. In order to provide insights into how the international community might help strengthen a sense of national integration in Timor-Leste, the activities are based loosely around those of foreign aid donors to the country. In particular, they refer to state-building activities that are most likely to 'build the nation'. Respondents were asked to indicate the three most important activities from a list of 10 (Table 10). Respondents viewed improving health as the most important way to build the nation, with 94 per cent of respondents ranked this activity in their top three preferences. In second ranking overall (though dominating first preferences), 75.5 per cent listed improving education, while improving infrastructure was viewed as the next most important (64\%). Notably, strengthening national government administration and traditional leadership were both viewed as more important than strengthening district administration, which - in the form of the decentralization agenda - has been a key focus of both international and domestic state-building assistance until its recent postponement to 2014. 
Table 10. To build the nation of Timor-Leste, which of the following do you rate as most important, the 2nd most important, and the 3rd most important? (\% of respondents) $2010(n=360)$

\begin{tabular}{lcccc}
\hline Group & $\begin{array}{c}\text { Most } \\
\text { important }\end{array}$ & $\begin{array}{c}\text { Second most } \\
\text { important }\end{array}$ & $\begin{array}{c}\text { Third most } \\
\text { important }\end{array}$ & Combined \\
\hline Improving health & 37 & 50.5 & 6.5 & 94 \\
Improving education & 50 & 21 & 4.5 & 75.5 \\
Improving infrastructure (e.g. roads) & 5.5 & 15 & 43.5 & 64 \\
Strengthening national government & 3.5 & 4 & 13 & 20.5 \\
administration & 1.5 & 4.5 & 12.5 & 18.5 \\
Improving communication between & & & & \\
different areas & 1 & 2 & 10 & 13 \\
Strengthening traditional leadership & 1 & 2 & 7 & 10 \\
Improving gender equality & 1 & 1 & 2 & 4 \\
Strengthening district administration & & &
\end{tabular}

\section{Conclusion}

As the most educated section of the demographically dominant youth population, tertiary students represent an important group in Timor-Leste, and one likely to contribute strongly to future decision-making elites. For these reasons, understanding tertiary student attitudes to national identity offers important insights into nation-building 'fault lines' in post-independence, post-crisis Timor-Leste. Unlike previous surveys, which examined aspects of an intergenerational conflict over post-independence political settlements (Leach 2003, 2008), this article has examined the longitudinal evidence for differences in attitudes between students from eastern and western districts. It has been argued that the few significant differences in attitudes - which peaked in the 2007 survey - were associated with the overt politicization of regional identity within Dili, and perceptions that East Timorese returning from the diaspora were dominating the post-independence national leadership, rather than with any genuine 'ethnic' or 'regional' variation in attitudes. These factors were intensified by conflicts intimately associated with ruralurban migration to Dili in the UNTAET and post-independence period.

In particular, the 2007 findings show clear evidence of students from western regions having significantly stronger assessments of the importance of 'having lived in Timor all of one's life'. The longitudinal findings also demonstrate a rise in the relative strength of sub-national forms of identification from 2002 to 2007, but a notable decline in sub-district and district affiliations in the 2010 survey. By 2010, the very few areas of significant difference asso- 
ciated with students' region of origin revolved clearly around the politics of rural-urban migration. The survey also highlights the ongoing importance of tradition and adat in understandings of political community, but reveals significant gender differences in attitudes towards the role of traditional authorities, with female students demonstrating significantly lower levels of preference for traditional authorities in dispute resolution situations.

The longitudinal survey also clearly charts significant fluctuations in key areas of national pride from 2002 to 2010, with notable declines in pride in East Timorese democracy, and pride in inter-group tolerance between 2002 and 2007, but a significant partial recovery in 'pride in Timor-Leste's democracy' from 2007 to 2010. Another positive finding relates to a survey question which asked respondents how willing or unwilling they would be to move country if doing so would 'improve their work or living conditions'. In the wake of the 2006 crisis, the percentage of respondents indicating they were 'very willing' to leave Timor-Leste had increased from $49 \%$ in 2002, to $61.5 \%$ in 2007. By 2010, this figure had dropped to $42 \%$, indicating a greater sense of confidence among East Timorese students in Timor-Leste's economic future.

While the 2010 survey findings offer some encouraging signs in relation to key nation-building 'fault lines' that have challenged Timor-Leste's sense of political community since independence, they also highlight ongoing latent tensions associated with the shifting urban politics of Dili. Equally they highlight the fact that the ongoing process of democratic consolidation in Timor-Leste will need to accommodate the continuing importance of traditional political authority, while meeting modern citizenship-based demands for equality in relation, for example, to women's political participation. Developing successful and effective hybrid governance institutions capable of accommodating these distinct conceptions of political community will remain a challenging task. These are factors to be considered in the coming large-scale withdrawal of international state-building forces in late 2012.

\section{References}

Anderson, Benedict

1983 Imagined communities: Reflections on the origin and spread of nationalism. London: Verso.

1993 'Imagining East Timor', Arena Magazine 4:24-5.

Borgerhoff, Andre

2006 'The double-task: Nation-building and state-building in Timor-Leste', Chandler, David European Journal of East Asian Studies 5-1:101-30. 
Chesterman, Simon

2004 You, the people: The United Nations, transitional administration, and statebuilding. Oxford: Oxford University Press.

Cummins, Deborah

2011 'The problem of gender quotas: Women's representatives on TimorLeste's suku councils', Development in Practice 21-1:85-95.

Dinnen, Sinclair

2007 'Thetwin processes of nation building and statebuilding', State, Societyand Governance in Melanesia Program. http://ips.cap.anu.edu.au/ssgm/publications/briefing_notes/PolicyBriefingNote_NationBuilding_25Aug.pdf (accessed 22-6-2012).

Direcção Nacional de Estatística

2006 Censo da população e habitação. Dili: National Directorate of Statistics/ United Nations Population Fund.

2010 'Highlights of the 2010 census main results in Timor-Leste', Timor-Leste Ministry of Finance. http://dne.mof.gov.tl/published/2010\%20and\%20 2011\%20Publications/Census\%20Summary\%20English/English\%20

Dodd, Mark Census\%20Summary\%202011.pdf (accessed 22-6-2012).

2008 'Gusmao's \$15m rice deal alarms UN', The Australian, 7 July.

Grove, Natalie, Kiera Zen, Eurosia Bucar, Luis Moniz Cardoso Pereira, Geovana Fernandes and Noemia Amaral

2007 Like stepping stones in the river: Youth perspectives on the crisis in Timor-Leste. Dili: Plan Timor-Leste. http://www.sphcm.med.unsw.edu.au/SPHCMWeb.nsf/resources/Timor-Leste_Final_Stepping_Stones.pdf/\$file/ Honneth, Axel Timor-Leste_Final_Stepping_Stones.pdf (accessed 22-06-2012).

1995 The struggle for recognition: The moral grammar of social conflicts. Translated by Joel Anderson. Cambridge: Polity. [Originally published as Kampf um Anerkennung: Zur moralischen Grammatik sozialer Konflikte. Frankfurt am Main: Suhrkamp, 1994.]

Jacobsen, Michael

1997 'Vanishing nations and the infiltration of nationalism: The case of Papua New Guinea', in: Robert J. Foster (ed.), Nation making: Emergent identities in postcolonial Melanesia, pp. 227-49. Ann Arbor: University of Michigan Press.

Joliffe, Jill

1978 East Timor: Nationalism and colonialism. St. Lucia: University of Queensland Press.

Jones, F. and P. Smith

2001 'Diversity and commonality in national identities: An exploratory analKammen, Douglas ysis of cross-national patterns,' Journal of Sociology 37-1:45-63.

2010 'Subordinating Timor: Central authority and the origins of communal identities in East Timor', Bijdragen tot de Taal-, Land-en Volkenkunde 166:244-69.

'Master-slave, traitor-nationalist, opportunist-oppressed: Political metaphors in East Timor,' Indonesia 76:69-85. 
Kingsbury, Damien and Michael Leach

2007 'Introduction', in: Damien Kingsbury and Michael Leach (eds), East Timor: Beyond independence, pp. 1-16. Clayton: Monash University Press. [Monash Papers on Southeast Asia 65.]

Leach, Michael

2009 'Difficult memories: The independence struggle as cultural heritage in East Timor', in: William Logan and Keir Reeves (eds), Places of pain and shame: Dealing with 'difficult heritage', pp.144-61. London: Routledge. [Key Issues in Cultural Heritage.]

2008 'Surveying East Timorese tertiary student attitudes to national identity: 2002-07', South East Asia Research 16-3:405-31.

2006 'East Timorese history after independence', History Workshop Journal 611:222-37.

2003 'Privileged ties: Young people debating language, heritage and national identity in East Timor', Portuguese Studies Review 11-1:137-50

2002 'Valorising the resistance: National identity and collective memory in East Timor's Constitution', Social Alternatives 21-3:43-7.

Matsuno, Akihisa

2010 'Analysing Timor-Leste electoral politics from a socio-economic perspective', in: Michael Leach, Nuno Canas Mendes, Antero B. da Silva, Alarico da Costa Ximenes and Bob Boughton (eds), Understanding Timor-Leste, pp. 330-4. Hawthorn: Swinburne Press. [Proceedings of the Understanding Timor-Leste Conference, Universidade Nasional TimorLorosa'e, Dili, Timor-Leste, 2-3 July 2009.]

Miller, D.

1999 'Bounded citizenship', in: Kimberly Hutchings and Roland Dannreuther (eds), Cosmopolitan citizenship, pp. 60-80. Basingstoke: Macmillan, New York: St. Martin's Press.

Nicol, Bill

2002

Timor: A nation reborn. Jakarta: Equinox.

Nixon, Rod

2006

'The crisis of governance in new subsistence states', Journal of Contemporary Asia 36-1:75-101.

Nussbaum, M.

2004 'Beyond the social contract: Capabilities and global justice', Oxford Development Studies 32-1:4-18.

Queiroz, Mario de

2011 'Portugal: Brain drain still bleeding ex-colonies dry', Inter Press Service News Agency. http://www.ipsnews.net/2007/09/portugal-brain-drain-

Ramos-Horta, José still-bleeding-ex-colonies-dry (accessed 22-6-2012).

$1996 \quad$ Nobel lecture. Stockholm: Nobel Foundation.

Scambary, James

2009 'Anatomy of a conflict: The 2006-7 Communal Conflict in East Timor', Conflict, Security and Development Journal, Routledge, 9-2:265-288

Taylor-Leech, Kerry

2008 'Language and identity in East Timor: The discourses of nation building', Language Problems \& Language Planning 32-2:153-180. 
2007 The Ecology of Language Planning in Timor-Leste: A study of language policy, planning and practices in identity construction, PhD dissertation, Griffith University, Brisbane.

Trindade, José and Bryant Castro

2007

'Rethinking Timorese identity as a peacebuilding strategy: The Lorosa'eLoromonu conflict from a traditional perspective', Indonesia Publications. http://www.indopubs.com/Trindade_Castro_Rethinking_Timorese_ Identity.pdf (accessed 25-6-2012). 